\title{
A POLICY RESPONSE TO THE E-COMMERCE REVOLUTION: THE CASE OF BETTING TAXATION IN THE U.K.
}

forthcoming in the Economic Journal, May 2002

\author{
Dr. David Paton* \\ Senior Lecturer in Industrial Economics \\ Nottingham University Business School \\ Wollaton Road-Jubilee Campus \\ Nottingham NG8 1BB \\ Tel: (0115) 8466601 \\ Fax: (0115) 8466667 \\ Email: David.Paton@Nottingham.ac.uk \\ Professor Donald Siegel \\ Professor of Industrial Economics \\ Nottingham University Business School \\ Wollaton Road-Jubilee Campus \\ Nottingham NG8 1BB \\ Tel: (0115) 8466629 \\ Fax: (0115) 8466667 \\ Email: Don.Siegel@Nottingham.ac.uk

\section{Professor Leighton Vaughan Williams} \\ Professor of Economics and Finance \\ Nottingham Trent University \\ Burton Street \\ Nottingham NG1 4BU \\ Tel: (0115) 8485516 \\ Fax: (0115) 8486829 \\ Email: Leighton.Vaughan-Williams@ntu.ac.uk
}

\section{*Corresponding Author}

We are grateful to numerous officials at Her Majesty's Customs and Excise and to the Horserace Totalisator Board for providing data and advice regarding this research. We also acknowledge the helpful suggestions and comments of four anonymous referees.

JEL Classifications: H21, H25.

Key words: taxation, e-commerce, betting, gambling 


\title{
A Policy Response to the E-Commerce Revolution: The Case of Betting Taxation in the U.K.
}

\begin{abstract}
$\underline{\text { Abstract }}$
Several environmental changes in the 1990s, including the introduction of a national lottery, the rise of Internet gambling, and the reduction of trade barriers within the European Union, induced the U.K. Government to initiate a large-scale review of betting duty. As a result of this review, the Government recently announced a significant reduction in betting taxes.

They also decided to replace the current general betting duty (GBD), levied as a proportion of betting stakes, with a gross profits tax (GPT), based on the net revenue of bookmakers. We examine the economic rationale behind these decisions and demonstrate how these tax changes have broad implications regarding optimal levels of taxation for other sources of government revenue.
\end{abstract}




\section{A Policy Response to the E-Commerce Revolution: The Case of Betting Taxation in the U.K.}

\section{Introduction}

Excise duties, chiefly from petrol, alcohol, cigarettes and gambling, constitute approximately $10 \%$ of U.K. Government revenue. In recent years, actual revenues from such duties have been significantly less than projected revenues, due to shifts in tax and trade policies and technological change, which have induced substitution within and across national borders. One such policy initiative was the reduction in trade barriers within the European Union, which has exposed structural differences in excise duty rates across nations. For example, excise rates on alcohol, cigarettes, and petrol are considerably higher in the U.K. than in some neighbouring countries. In each of these cases, U.K. suppliers have become especially vulnerable to competition from lower-tax countries. A related problem has been the growth of illegal imports of alcohol and cigarettes. These threats have led consumers and industry representatives to demand that the U.K. Government reduce excise duties. ${ }^{1}$

Pressure to reduce betting duty has been particularly intense, due in part to the rapid rise of Internet gambling. Internet gambling allows U.K. bettors to avoid excise duty by placing wagers with offshore or overseas companies. Thus, the Internet poses a threat to government revenue streams and to the competitiveness of the U.K. gambling industry. The prevailing sentiment among U.K. policymakers and practitioners is that such threats will become more severe, unless tax policies are substantially modified.

As a result of this review, the Chancellor of the Exchequer announced a major reduction in the overall level of betting taxation in his budget statement of April 2001. He also announced that 'General Betting Duty', levied as a proportion of betting stakes, would be replaced by a 'Gross Profits Tax' based on the net revenue of bookmakers. The

\footnotetext{
${ }^{1}$ Even so, the influence of the EU Single market on gambling is likely to be of relatively limited
} 
Chancellor proposed a tax rate of $15 \%$ for fixed-odds and pari-mutuel bookmakers, $10 \%$ for sports spread bookmakers and 3\% for financial spread bookmakers.

Spread bookmakers operate by offering a spread around a quantifiable future event, which can be bought or sold by bettors, much like a 'future'. These companies are regulated as financial services, rather than bookmaking. The rationale for the lower tax rate on spread bookmakers is that the cost of operating such a business is higher than for fixed-odds bookmakers, especially for financial spread bookmaking. Moreover, the turnover tax, which existed before the change in policy, constituted a much smaller fraction of the profits of spread bookmakers than their fixed-odds counterparts. Thus, a direct shift from a turnover tax to a single rate of GPT would be likely to cause a significant 'shock' to the profitability of spread betting companies.

The decision to change from a turnover tax to a Gross Profits Tax was made following a consultation process involving representatives of the bookmakers and independent analysis undertaken by the authors and others. Final recommendations were issued by officials of HM Customs and Excise to HM Treasury, following a bargaining process between the Government and large betting firms. Specifically the largest firms in the betting industry, including the 'Big Four' (Ladbrokes, William Hill, Coral and the Tote), agreed to transfer their off-shore business back to the U.K., in conjunction with the implementation of the change in the level and structure of betting taxation.

Although revenue from gambling constitutes the smallest of the four goods subject to excise duties (i.e., petrol, alcohol, cigarettes and gambling), the consequences of this dramatic change in betting tax policy could have important implications for policy towards duties on petrol, alcohol and cigarettes. Also, similar policy debates on the taxation of gambling and the impact of e-commerce have emerged in other OECD countries, most notably, Australia 
(Smith, 2000) and the U.S. (Goolsbee, 2001). ${ }^{2}$ Thus, legislators, academics, and practitioners in many nations will be closely monitoring the impact of this major shift in U.K. policy.

The purpose of this paper is to explore the economic rationale behind the U.K. Government's response to the e-commerce revolution and assess its likely effects on tax revenue, the gambling industry, and consumers. In the following section, we contrast policy perspectives on gambling in the U.S., U.K., and Australia. Section 3 provides some background information on the U.K. betting industry and the characteristics of these markets. The following section describes the key environmental changes that have provided an impetus for the shift in tax policy. Section 5 evaluates the proposed policy shift against several criteria, with a particular focus on economic efficiency. The final section consists of conclusions and suggestions for additional research.

\section{Policy Perspectives on Gambling in the U.S., U.K., and Australia}

There are salient differences in policy and social perspectives on the gambling industry in the U.K., U.S., and Australia, which we summarise in Table 1.

In the U.S., most of the major policy issues are resolved at the state level, since state legislatures have jurisdiction over most aspects of gambling. An important secular trend in the U.S. is that gambling, especially in the form of lotteries and electronic gaming devices (e.g., slot machines), has become much more socially acceptable. Most U.S. states now have lotteries, which are often used to fund politically popular education programs. ${ }^{3}$ In 1978 , only one state, Nevada, allowed casino gambling. By 1999, 27 states had authorised some form of casino gambling. Eadington (1999) reports that gambling revenues have risen almost threefold over a 15 year period, rising from approximately \$17 billion in 1982 to approximately \$51 billion in

\footnotetext{
${ }^{2}$ In the U.S. Goolsbee (2000) finds that Internet commerce is highly sensitive to changes in state sales taxes.

${ }^{3}$ See Clotfelter and Cook (1989) for trenchant analysis of the rise of lotteries in the U.S.
} 
1997 (in constant dollars), with most of the increase attributed to the spread of lotteries and casinos. Christiansen (1998) estimates that gambling accounts for approximately $10 \%$ of leisure expenditures.

The growth in casino gambling is mainly due to the rise of Native American (Indian) casinos and riverboat casinos. Indian casinos are assigned to a particular local tribe. Under U.S. law, these tribes are considered sovereign nations, and thus, are not required to pay taxes to states. While tribal casinos in remote, rural areas are typically quite small and unprofitable, those located near major metropolitan areas (e.g., New York City, Boston, Phoenix, Miami/Ft. Lauderdale, and Minneapolis) yield high financial returns. Riverboats, which are subject to taxes, are especially popular in the Southern and Midwestern states.

Despite the growing popularity of gambling in the U.S., there is still strong religious opposition to this activity in many states and almost no support for legalising gambling on sporting events. For instance, only two U.S. states allow sports betting: Nevada and Oregon, and in Oregon, it is permitted only on a very limited basis. Thus, there is considerable variation within the U.S. in gambling activity and tax rates across regions and states.

In the U.K., gambling is relatively socially acceptable and has rarely engendered any strong religious opposition. Regulation and taxation issues are resolved at the national level. Also, casinos are not as popular in the U.K. Finally, a major source of revenue growth in the U.K. industry is the rise in gambling on sporting events, including spread betting.

Perhaps the most striking difference between the U.S. and U.K. lies in the nature of the public policy debate regarding gambling. In the U.S., much of this debate focuses on the magnitude of externalities that arise with an increase in gambling. Opponents of the gambling industry tend to focus on negative externalities, such as the social costs of problem gambling and associated criminal activity. Some religious groups also oppose expansion of gambling on moral grounds. Supporters of the industry contend that gambling can be used to 
promote economic development and tourism in depressed areas, such as Indian reservations and inner-city neighbourhoods. They also argue that legalisation of gambling can help states avoid tax revenue leakage to neighbouring states that allow such activity. ${ }^{4}$

In 1996, the U.S. Congress mandated the National Gaming Impact Study Commission (NGISC), which recently released its final report (see http://www.ngisc.gov). The NGISC report focused mainly on the social and economic implications of the rise of gambling. It also contains a considerable amount of material on the pernicious influence of sports betting on the 'purity' of athletics, especially at the university level. The bottom line is that it is not likely that legalised sports betting will grow in the U.S.

In the U.K., many of the issues explored in the NGISC report are virtually absent from the public policy debate. Instead, the major focus appears to be on maintaining the viability and competitiveness of the industry. Likely reasons for this difference are that U.K. firms have established a strong competitive position in this sector and there is a high level of social acceptability regarding gambling. However, it is important to note that this industry does not operate in a vacuum. Environmental and tax changes will have implications for the level of gambling activity and more importantly, for substitutes and complements. We consider these factors in subsequent sections of the paper.

It is clear, then, that there are major differences in the nature of gambling activity and how it is perceived and regulated in U.K. and the U.S. While Sauer (2001) contends that cycles of regulation and deregulation of gambling activity in the U.S. are the result of contests between conflicting interest groups, such cycles are not apparent in the U.K. An explanation for this difference may lie in the fact that in the U.K. policy decisions are resolved at the national level, where the major political parties do not appear to have any critical disagreements.

\footnotetext{
${ }^{4}$ See Gazel (1998) for a discussion of these issues. He concludes that casinos have generated net economic losses for most states.
} 
An example of this non-partisan approach was the publication in July 2001 of the report of the Gambling Review Body, established by the U.K. Government to review the betting and gaming industry and to generate a set of proposed recommendations. In this report, the authors endorse further de-regulation of the industry to encourage the growth of 'betting complexes' or licensed betting offices (LBOs). These LBOs would be permitted to expand the range of betting mediums they offer, notably to increase the allowed number and payout maximum of casino-type games of chance. The report also proposes additional deregulation of casinos, including allowing the consumption of alcohol on the casino floor and abolishing the current 24-hour cooling-off period before permitting access to a casino. On the other hand, apart from casinos, the authors recommend that betting not be permitted in establishments where alcohol is served or in establishments that are not licensed primarily for the purpose of betting. The overall thrust of this report is to promote de-regulation of gambling within a regulated licensed betting environment.

As evidenced in Table 1, Australia falls somewhere in between the U.S. and the U.K. Policymaking occurs at both the state and national levels. Smith (2000) reports that in Australia, as in the U.S., States have become increasingly dependent on gambling taxes as a source of revenue. The author also finds that the growth in gambling tax revenue in Australia is being fuelled by casinos and electronic gaming devices. While gambling has traditionally been socially acceptable, bookmakers operate on-course only. In contrast to the U.S. and U.K., Australia has experienced more rapid growth in Internet gambling. Finally, although the primary focus of the public policy debate is on maintaining industry competitiveness, as in the U.K., there has been some consideration given to the issue of negative externalities associated with gambling.

It was such concerns that led the Australian Government to impose a ban on new virtual casinos. This ban was not applied to other forms of gambling, such as dog racing, 
horse racing, or sports events. As in the U.S., casinos and casino-type establishments are quite popular in Australia. In particular, betting in cafés and so-called 'TAB' (the Australian ‘Tote') bars are widespread in Australia, and so-called 'pokie' machines (electronic poker or fruit machines) are prevalent outside of formal gambling and gaming establishments.

In the following section, we present background information on the U.K. betting industry and the characteristics of these markets.

\section{Characteristics of U.K. Betting Markets}

Over $£ 8$ billion was spent on betting in the U.K. in 2000, generating more than $£ 500$ million in General Betting Duty. The betting industry consists of three distinct sectors: off-course betting at licensed outlets (the dominant venue), on-course betting (which is not subject to General Betting Duty), and betting by telephone (through deposit or credit accounts, or via debit cards). $80 \%$ of all betting turnover is generated off-course, in LBOs (Licensed Betting Offices), about $10 \%$ of turnover is on-course with the remainder consisting mainly of telephone betting. There is also a growing market for wagering via the Internet and interactive betting through the television. Betting can be further sub-divided into fixed-odds betting with bookmakers, pool (parimutuel) betting with the Horserace Totalisator Board (the Tote), ‘spread betting’ and bet brokerage.

In fixed odds betting, wagers are settled at specific odds. This is the major form of betting in the U.K. In pool betting, winning bettors share the pool of all winning bets, net of fixed deductions. Within the off-course market, pool betting plays a very small role. In addition to straight win bets, there are a wide variety of other types of bets available. These include 'each way' bets, allowing the bettor to nominate win and place (usually in the first three), multiple bets on cumulative outcomes, and forecast bets which involve nomination of the first two or three past the post in the correct order. 
Spread betting companies operate by establishing a market for uncertain outcomes, such as the price of gold or the number of goals in a football match. The market makers set a 'spread' regarding a specified outcome, and clients of these companies are invited to buy at the top end of the spread or sell at the bottom end. The outcome of the trade is calculated as the number of units by which the actual outcome differs from the level at which the trade is enacted. Spread or 'index’ trades are available on numerous financial instruments, including stock market indices, various types of options, and futures on government bond, currencies, and commodities. Spread betting is still, however, a very small segment of the gambling industry, particularly in terms of the proportion of all bets placed, and the number of bettors involved. For example, it is estimated that revenue from spread betting makes up little more than $0.2 \%$ of general betting duty (Paton, Siegel and Vaughan Williams, 2000).

A form of betting which is even more novel than spread betting is 'bet brokerage' in which the bookmaker acts as an intermediary (for a small commission) to match up clients who lay and accept bets among themselves. This constitutes a very small percentage of total betting turnover.

Traditionally, this industry has been highly concentrated. Three large bookmaking chains dominate the off-course fixed odds market: Ladbrokes, William Hill, and Coral. These three firms account for $60 \%$ of the turnover in off-course licensed betting offices. Along with Tote Credit, they account for $90 \%$ of the telephone betting market. Recent efforts by Ladbrokes to acquire Coral suggest further consolidation is likely in this sector. There are currently four companies, regulated by the Securities and Futures Authority, operating in the spread-betting sector:, IG Index, , Sporting Index, Spreadex, and Cantor Index..

Over $70 \%$ of wagers in betting offices are on horse racing. However, according to the 1998 Monopolies and Mergers Commission report on this industry, the share of football betting is increasing, especially by telephone, via the Internet, interactive TV and through 
spread betting. For example, in 1997, 4.3\% of betting office turnover was on football compared to 8\% of turnover by telephone (MMC, 1998, p.81). In the spread betting market, the majority of turnover is on football betting. Industry experts predict that football betting will also fuel the growth of Internet betting.

The Mintel (2001) survey of adults aged 18+ found that in a period of six months while $68 \%$ had bet on the National Lottery, only $11 \%$ had bet on any form of sports betting in a betting office (although this rose significantly since 1997). Just $8 \%$ bet on the football pools and $3 \%$ in a casino.

A key trend has a precipitous decline in the amount wagered on football pools. Between 1993 and 1999, such turnover has dropped by about 60\%. Although the number of bingo clubs also fell sharply between 1993 and 1999, turnover has recently sharply recovered. This could be due to additional de-regulation of this sector, which has led to more AWPs (Automated Win Payout 'Slot Machines'), higher prizes, and further promotional opportunities.

On-shore bookmakers are subject to payment of $6.75 \%$ on turnover, as well, at the present time, to an additional levy on horse racing turnover, which averages about $1.25 \%$, but varies on a sliding scale linked to turnover. These costs are typically passed on to customers in the form of a $9 \%$ 'tax' on stakes or deduction from payouts. The issue of taxation of financial spread betting is different than taxation of sports spread betting, due to the special need in the financial spread betting sector to hedge bets in conventional financial markets, as part of the risk management procedures. A consequence of this financially oriented wager is that a losing trade for a client is often also, to a lesser extent, a losing trade for the bookmaker. Lastly, no duty is currently levied on 'bet brokerage' systems of betting.

Quarterly data for 1986-2000 on betting turnover are presented in Figure 1. These data are seasonally adjusted and an index for each series is presented. Five key events are 
denoted on the graph: the abolition of on-course duty at the end of March 1987, reductions in GBD in April 1992 and March 1996, the introduction of the National Lottery in November 1994, and the May 1999 announcement by Victor Chandler (a major firm in this industry) that it was establishing operations in Gibraltar. It is clear that from a peak in 1989, there has been a gradual downward trend in turnover, with the sharpest decline in the early '90s.

In the following section, we describe changes in the environment that provided an impetus for changes in the U.K betting tax.

\section{Changes in the Industry Environment}

A major factor in the U.K. Government's ultimate decision to reduce the betting tax was the rapidly changing competitive environment in this industry, due mainly to the growth of ecommerce and the introduction of the National Lottery. In this regard, it is helpful to distinguish between the Licensed Betting Office (LBO) sector and telephone/Internet betting. Three environmental changes have been especially important. Two of these are relevant primarily to the telephone/Internet sector and the third to the whole betting industry.

First and most obviously, there has been an increase in the incidence of Internet betting in recent years, with a substantial rise in the number of independent bookmakers offering Internet access to betting sites. Data on recent trends in betting turnover and gross profits of the five largest bookmakers indicate that turnover from Internet betting was just $0.1 \%$ of industry turnover in September 1999. Since then, the share of industry turnover derived from Internet betting has increased dramatically, rising from $0.2 \%$ in February 2000 to $0.7 \%$ in May (the last month for which data are available). Further, the Racing Post Usage and Attitudes Study (June, 2000) indicates that Internet access had increased by $50 \%$ in the previous eighteen months (12 to $18 \%$ with access to the Internet at home or work). This penetration was very much higher at the middle to upper end of the socio-economic 
groupings. Among Racing Post readers, 40\% had access to the Internet, with a further $9 \%$ intending to get access. These findings are broadly consistent with the findings of Datamonitor (2001), who predict that the number of online gamblers in the U.K. will expand rapidly as advertising proliferates and the technology becomes ubiquitous. They estimate that online gambling currently generates about \$700M in turnover the U.K. (July 2001), a figure that is expected to rise to more than $\$ 1.6 \mathrm{~B}$ by 2005 . The authors of this report assert that stronger regulation will inspire greater confidence in consumers, which will fuel some of the growth. They also predict that more sophisticated online offerings and improvements in the quality of the on-line experience will also serve to increase demand. Similarly, the Henley Centre, a leading U.K. forecasting company, predicts that the share of Internet gambling in the market will increase from 2\% in 2001 to 9\% in 2005 (Paton et al, 2000), a trend which is likely to enhance competition in this industry.

The key feature of the growing Internet/telephone sector is that competition is much more intense in this sector than in the LBO sector. For example, start-up costs for firms are much lower than those associated with High Street bookmakers, whilst search costs for consumers are quite low, in the sense that bettors can easily shop around and find bookmakers offering the best odds on a particular wager.

A second key environmental change is that several large bookmakers have established offshore operations, mainly in order to avoid the U.K. betting duty. The first was Victor Chandler, the U.K.'s leading independent rails bookmaker, who set up a firm in Gibraltar. Although, Victor Chandler's Gibraltar operation was not subject to the betting duty, the firm originally charged bettors a 3\% ‘administration charge' on bets. Subsequent competition has forced many on-line companies to waive 'tax' on bets altogether, at least in the short-term. More recently, the largest bookmaking chains, notably Ladbrokes, William Hill and Coral, have also developed offshore operations. 
Both of these environmental changes imply that U.K. telephone/Internet bookmakers are now competing in a global market with lower entry barriers and greater substitution possibilities, populated by firms who are subject to a much lower tax burden.

Concomitant with the rise of e-commerce has been an increase in the number and availability of substitutes for betting. The most important of these is the National Lottery, introduced in November 1994, along with subsequent National Lottery branded games such as Scratchards, the Thunderball draw and the National Lottery Extra draw. This development has meant that even though the LBO sector continues to be dominated by a few firms, who are able to exert considerable monopoly power, their influence has diminished somewhat in the face of increased substitution possibilities.

Taken together, these three trends pose a serious threat to the U.K. betting industry and, thus, to the tax base for betting duty. Based on these trends, we hypothesise that the demand for betting will be relatively elastic with respect to changes in the tax rate.

Unfortunately, there is very little evidence on the elasticity of demand for betting. Exceptions include the work of Suits $(1977,1979)$ who found that the demand for horse racing with respect to price in the U.S. was moderately elastic (-1.59). Paton, Siegel and Vaughan Williams (2001) report own-price elasticity estimates for U.K. betting that range from -1.19 to $-2.50 .^{5}$

A further motivation for the proposed tax reduction is its potential impact on the underground or shadow economy. In this context, we refer to illegal betting activity on which taxes are not paid. Schneider and Enste (2000) provide evidence of growth in the shadow economies of all OECD countries. In the U.K., the authors estimate that the percentage of GDP represented by the shadow economy has risen from $9.6 \%$ in 1990 to $13 \%$ in 1997.

\footnotetext{
${ }^{5}$ Several authors have analysed tax revenue from lotteries (e.g., Mikesell, 1994; Szakmary and Szakmary, 1995) or estimated the price elasticity of demand for lotteries (e.g. Gulley and Scott, 1993; Farrell
} 
Unfortunately, Schneider and Enste cannot disaggregate these figures by type of activity, such as tobacco, alcohol, drugs, prostitution, and gambling, so we cannot determine how much gambling activity has actually gone underground. More generally though, the authors attribute at least some of the rise in the shadow economy to increases in taxes on items such as alcohol and tobacco. It is interesting to note that the same individuals or groups that smuggle alcohol and tobacco, i.e., organised crime, can also potentially provide gambling services. This is certainly the case in the U.S.

The limited evidence that is available on elasticity of demand and the extent of the underground economy, together with the observed changes to the competitive environment suggest that, ceteris paribus, the proposed reduction in betting tax will lead to a large increase in turnover. If the overall tax burden on betting is not reduced, we predict a continuing decline in the U.K. betting industry and the tax base for betting duty.

One factor not considered thus far is the possibility that tax changes in a given gambling sector will affect tax revenue in other gambling markets and in related industries. The magnitude of such impacts will depend on the strength of substitution across different types of gambling and in related industries. There is some limited evidence on these effects in the U.S. and U.K. Siegel and Anders (1999) found that an expansion of riverboat gambling in Missouri was associated with a decline in revenue in other businesses in the entertainment and amusement sector. The same authors (Siegel and Anders, 2001) reported that an expansion in Indian casinos in Arizona was associated with a reduction in lottery revenues, especially for Lotto games. They did not, however, find evidence of substitution between horse and dog racing and lotteries. The strongest displacement effects were found for the big prize lottery games.

and Walker, 1998; Farrell, Morgenroth and Walker, 1999; Farrell, Hartley, Lanot and Walker, 2000; Forrest, Gulley, and Simmons, 2000), generally reporting an elasticity that is either close to or slightly greater than unity. 
In the U.K., Paton, Siegel, and Vaughan Williams (2001) find significant evidence of substitution between betting demand and the U.K. National Lottery. They estimate a cross price elasticity of Lottery turnover with respect to betting, which falls in the range of +0.63 to +1.61. This finding implies that a reduction in the betting tax will also result in lower lottery revenue, as some punters substitute from the Lottery to betting.

In the following section, we examine the welfare implications of two alternative tax regimes.

\section{Evaluating Changes to Betting Tax Policy}

The consultation document issued by HM Customs and Excise (2000) on modernising betting duty asserts that potential changes to betting taxation should be judged against criteria that include allocative efficiency, distributional efficiency, industrial competitiveness and the maintenance of government revenue. We attempt in this section to provide a framework for evaluating the proposed changes against each of these criteria. In our analysis, we assume for the sake of simplicity that incentive effects and ease of evasion will be similar under each. ${ }^{6}$

Conventionally, the quantity of output in betting markets is specified as the number of unit bets placed. Using $£ 1$ as the standard unit, the quantity of bets is equivalent to the total amount staked by punters. Further, the price of each unit bet is typically measured as the percentage of the stake that the punter expects to be returned in winnings. Based on this

\footnotetext{
${ }^{6}$ Another potentially important issue is the geographical incidence of the tax. For example, central to US and Australian gambling policy is taxation based on the location of the bettor rather than (as in the U.K.) based on the location of the bookmaker. In the U.S., out-of-State betting is prohibited, except in carefully defined circumstances. In the context of the U.K., the advantage of such a 'Place of Consumption' (POC) tax, levied on the bet based on where it is placed is that is might discourage UK bookmakers from establishing operations overseas, and be less easy to avoid. A potential disadvantage of a POC tax, however, is that it may encourage new bookmakers, with no Licensed Betting Office (LBO) operations, to establish solely as teleInternet operations, not register for the tax, and undercut the established U.K. betting sector. Moreover, a POC tax on a service such as betting may discriminate against domestic purchasers of the product in a manner that has negative political and trade implications. That is, it might explicitly encourage bookmakers to target overseas markets. Bookmaking is a highly controversial issue in the US, and a tax structure which, in effect,
} 
approach, the total revenue received by bookmakers is the amount they retain after paying out winnings (rather than the total amount of money received in stakes) and the so-called 'Gross Profits Tax’ is, in fact, a tax on net revenue. Thus, it follows that General Betting Duty, levied as the percentage of stakes, is equivalent to a commodity (or unit or specific) tax. On the other hand, the Gross Profits Tax is effectively levied as a proportion of the price charged to betters and is equivalent to an ad valorem tax, levied as a proportion of the price charged to consumers.

Having established this, the economic analysis of the proposed policy shift in the U.K. reduces to a standard comparison of commodity and ad valorem taxes. Such a topic has been the subject of a long-standing literature dating back at least as far as Wicksell (1896). It is easy to show that under perfect competition, an ad valorem tax leads to the same price and quantity equilibrium and is welfare equivalent to an equal-yield commodity tax. Figure 2 illustrates the simple case of a linear industry demand curve and constant marginal costs. A commodity tax levied at a rate of $c$ per unit bet shifts the marginal cost curve upwards. An ad valorem tax, levied at a rate of $v \%$ of the price, causes the average revenue curve faced by producers to swivel inwards around the intercept on the quantity axis. In both cases, the equilibrium price and quantity are $\left(P^{*}, Q^{*}\right)$ and tax revenue is equal to $c$ times $Q^{*}$.

A more interesting case occurs in the presence of imperfect competition, and many scholars have examined the relative incidence of each type of tax on consumers and producers. Several authors assess whether taxes will be 'over-shifted' or 'under-shifted' to consumers under a range of assumptions about market structure and interdependence of firms (Stern, 1987; Baker and Brechling, 1992; Delipalla and O’Connell, 2001). 
Of more direct relevance to the current policy debate is research assessing the relative impacts of each type of tax. There is a consensus in this literature that, in monopoly and oligopoly markets, an ad valorem tax generates a welfare-superior outcome relative to a commodity tax (for example, Delipalla and Keen, 1992). Furthermore, Skeath and Trandel (1994) find that for any unit tax imposed on a monopoly, "there exists an ad valorem tax...that produces larger profit, tax revenue and consumer surplus” (p.53). The authors also show that this result generalises to all symmetric Cournot-Nash oligopolies. For the nonsymmetric case, the result holds only given certain conditions. Specifically, an ad valorem tax is more likely to welfare dominate a unit tax that raises an equal amount of revenue when the number of firms in the market is small and when elasticity of demand in the market is relatively high (p. 67). These conditions correspond directly to the situation in U.K. betting markets in which the LBO sector at least is dominated by very few firms and elasticity of demand is likely to be decreasing due to the environmental changes outlined above. Even in the case where the conditions for welfare dominance are not satisfied, Skeath and Trandel (1994) show that consumer surplus will still be higher under an equal yield ad valorem tax.

Figure 3 illustrates this in the context of a pure monopoly. Tax revenue under the commodity tax is given by the equilibrium quantity, $\mathrm{Q}^{*}$, times $c$. Under the ad valorem tax, revenue is given by $\mathrm{Q}^{*}$ times the difference between $A R$ and $A R(v)$. In order to achieve the same equilibrium price and quantity in each case, it is clear that $(A R-A R(v))$ must be greater than $c$ and that revenue under the ad valorem tax is higher. It directly follows that a revenue equivalent ad valorem tax will result in lower prices and higher turnover in equilibrium, than will a commodity tax.

The intuition behind these theoretical results is that an ad valorem tax (such as the GPT) provides an incentive for firms that have some price-setting ability to follow a lowmargin/high-turnover strategy rather than the low-turnover/high-margin strategy encouraged 
by a commodity tax (such as GBD). A related issue is that the GPT provides more favourable incentives for firms to innovate and to improve their technical efficiency in that the resultant lower prices (due to lower costs) induce lower taxation. ${ }^{7}$

The majority of empirical applications of such models use data on cigarette taxes. For example, Delipalla and O’Donnell (2001) use data from a range of European countries to confirm that commodity taxes do indeed have a greater impact on prices than ad valorem taxes. Given that the cigarette industry possesses many similar characteristics to betting, i.e., it is highly concentrated and faces a similar threat from 'imports' being sold at tax free prices (in the case of cigarettes, illegally so), this evidence is likely to be relevant to betting markets.

In summary, the available theoretical and empirical evidence suggests that the proposed switch from GBD to a GPT will, at worst, have a neutral impact on allocative efficiency and welfare losses in the U.K. betting industry. The greater the extent of monopoly power in the industry, the greater will be the efficiency benefits of a gross profit tax. Despite the increased competition from the Lottery and other forms of betting, there is clear evidence of high margins and monopoly pricing in the larger LBO sector of the U.K. market (see, for example, Paton and Vaughan Williams, (2001). Consequently, the move to the GPT is likely to bring significant efficiency gains in this sector.

The telephone/Internet sector operates on much lower margins and gains from allocative efficiency are much less likely here. However, a key issue facing this sector in particular is the threat of international competition from companies that operate off-shore and thus, can avoid paying duty. In light of this, the GPT still offers a considerable advantage to U.K. companies operating in this competitive sector. With a turnover tax, if margins are squeezed due to competition, the level of duty payable is not altered. On the other hand, with a GPT, if margins are reduced, the level of duty is automatically lower. In other words, the

\footnotetext{
${ }^{7}$ We are grateful to a referee for this point.
} 
GPT provides an automatic adjustment mechanism to companies in the face of changes to the competitive environment. In industry segments where competition is intense (e.g., Internet and telephone betting), the tax burden will be relatively light. In sectors that are characterised by less intense competition (e.g., licensed betting offices), the tax burden will be relatively high. If competition is so intense that any non-zero level of tax renders it impossible for U.K. bookmakers to survive in this sector, then the choice between GBD and a GPT is irrelevant. However, given that the political situation is such that a zero tax rate for this sector is unrealistic in the short or medium term, the GPT still offers considerable advantages even to the telephone/Internet sector. There is also reason to believe that U.K. bookmakers have an advantage in terms of reputation for probity that might temper price competition.

The corollary of the beneficial impact of a GPT on the competitiveness of U.K. firms is that changes in the competitive environment will result in automatic adjustments to government revenue. These adjustments will occur because tax revenue from a GPT will depend on the price charged, which is itself determined by the market environment. An increase in competition will lead to a decrease in tax revenue. Thus, the ad valorem type tax is likely to lead to a much less secure stream of government revenue than the commodity type tax. In effect, the move to a GPT would shift the burden of risk away from the private sector and on to the Government.

Paton, Siegel, and Vaughan Williams (2000) outline a simple model of the U.K. betting market, in order to estimate the impact on prices and tax revenue of a switch from GBD to a GPT. Their analysis is based on a range of different assumptions regarding the extent of monopoly power and the magnitude of the demand elasticity with respect to tax. Some summary results of this model are reported in Table 2. The model requires estimates of price, quantity, and the elasticity of demand for betting with respect to deductions. During 
1999, total U.K. betting turnover subject to GBD was $£ 7.3$ billion pounds, whilst the mean price for the whole industry is estimated to be close to 0.23 (23\%). The authors use 'high' and 'low' elasticity scenarios and simulate the rates of a GPT that would be revenue equivalent to the current value of the commodity tax under different assumptions regarding the extent of monopoly power in the industry.

In the case of perfect competition, equilibrium price and quantity are unchanged with a switch to a GPT and the revenue equivalent GPT rate is equal to $29.3 \%\left(=t / P^{*}\right.$ where $t$ is the current level of GBD and $\mathrm{P}^{*}$ is the current equilibrium price). For every other assumption relating to the extent of monopoly power, the equilibrium price is decreased and quantity increased on a move to a revenue equivalent GPT regime. In fact, there is considerable evidence (see Monopolies and Mergers Commission, 1998) suggesting that bookmakers in the off-course market have significant market power. Using the mid-point assumption for the monopoly power coefficient, Paton et al (2000) find the simulated revenue equivalent GPT rate to lie between 0.252 and 0.271 . This implies a reduction in equilibrium price to between 0.215 and 0.213 and an increase in betting turnover of between 17 and $25 \% .^{8}$

The proposal to introduce GPT at a rate of $15 \%$ represents a significant reduction in the overall burden of taxation on betting. This implies an even lower equilibrium price and, consequently, a further boost to turnover. Despite this effect, the proposed rate of duty almost certainly implies a significant decrease in government revenue from betting.

\footnotetext{
${ }^{8}$ Paton, Siegel, and Vaughan Williams (2001) show that this assumption implies that just over four pence out of each pound bet is taken as monopoly profits. The figures used imply that a typical $£ 1$ bet in an offcourse shop would be broken down as follows:

Analysis of profit margins within the industry using published accounts data and additional information supplied by Customs and Excise suggests that the largest bookmakers have a profit margin about 4 percentage points
} 
However, given the rapid change in technology and growth of competition, it is likely that maintaining the status quo would also result in a significant decrease in tax revenue. If the tax reduction is successful in boosting consumer demand and in reducing the off-shore operations of U.K. bookmakers, government revenue may well be higher in the long run than under the 'no action' scenario.

Another economic issue that arises from our analysis of the impact of tax changes is the importance of substitution. It is reasonable to assume that a decline in the price of betting, arising from a switch to an ad valorem type tax and/or from a decrease in the overall level of taxation, will reduce the demand for substitute products. As noted in the previous section, Paton, Siegel and Vaughan Williams (2001) report evidence of a high degree of substitution between the National Lottery and betting markets. Thus, any decrease in betting taxes is likely to lead to a decrease in government revenue from the lottery (which is currently taxed at a rate of $12 \%$ of sales). ${ }^{9}$ A natural extension of this analysis is to examine substitution and revenue impacts beyond gambling. Understanding these substitution effects is critical to providing an accurate estimate of the global impact on tax revenue of a reduction in betting duty, since several potential substitutes for gambling constitute significant sources of tax revenue for the U.K. government. For example, casual observation suggests that tobacco consumption is prevalent at U.K. betting establishments. Thus, it would be interesting to examine the impact of a change in a gambling tax on the demand for alcohol and tobacco.

Another area of concern relates to distributional or equity issues associated with the tax policy change, i.e., whether the shift to a GPT will have an adverse affect on small firms.

higher than smaller bookmakers. If we take mean profit margins for the latter to be representative of a normal rate of return, this lends credence to our assumption.

${ }^{9}$ Although total receipts from all gambling duties in the UK are significant ( $£ 1.51$ billion in 1999/2000, for example), their share of total government revenue is less than $1 \%$ and the (direct) public finance implications of the change to betting duty seem minimal. 
We consider two issues here. The first is the possibility that larger bookmakers can exploit economies of scale and thus, have substantially lower costs than their smaller rivals. The second is the fact that large bookmakers in the U.K. may attract a higher proportion of high margin business than do small bookmakers. Specifically, it appears that large bookmakers derive a higher percentage of their turnover from highly profitable betting on customised numbers games.

Considering the cost differential first, tax models can easily be extended to a case in which large firms have lower costs than small firms. Assume that large firms set the market price at a level sufficient to provide them with monopoly profits. Small firms only achieve normal profits and are effectively sheltering under the monopoly price set by the larger firms. As we have seen, the switch to a GPT is likely to lead to a lower equilibrium price relative to GBD. In this case, it is conceivable that this switch would result in bankruptcy for some small, marginal bookmakers. One interpretation of this exit is the failure of inefficient firms, in the face of increasing competition. It is important to note, however, that increased concentration may have a countervailing negative impact on long-run efficiency. Also, there might be important social and political considerations that make the exit of small bookmakers undesirable.

The issue of whether small bookmakers attract a greater proportion of low margin business is less ambiguous. As argued above, a GPT is effectively a tax on margins or prices. Low-priced betting products will attract a lower rate than high-priced products.

Consequently, the shift to a GPT, other things being equal, is likely to benefit small firms relative to the larger firms. For example, consider two $£ 1$ bets on alternative betting products. The first product is offered by large bookmakers and returns 50 pence to the bettor before tax. The second product is offered by a small bookmaker and returns 90 pence. Under a turnover tax of $10 \%$, both firms will pay a tax of 10 pence and tax revenue is 20 
pence. The gross profits from the two bets are 60 pence, so a GPT of $33.3 \%$ would be required to maintain revenue. At such a rate, the large firm would have to pay tax of 16.7 pence and the small firm only 3.3 pence. On balance, there seems insufficient evidence to support concerns that the small bookmakers will be relatively worse off under the new policy regime.

\section{Conclusion}

The U.K. Government has decided to base its betting taxation policy on economic criteria, such as reducing allocative inefficiency and maintaining competitiveness. This contrasts significantly with the approach taken by other countries such as the U.S. and Australia, where an assessment of the social costs of gambling has played a much more important role in the consideration of policies regarding betting activity.

The decision to reduce the overall level of betting taxation in the U.K. demonstrates an awareness of the fact that market conditions in the betting industry have fundamentally changed in recent years. Also, the switch from General Betting Duty (GBD) to a Gross Profits Tax (GPT) appears to have been directly influenced by economic theory on betting taxation. Specifically, the current method of levying duty on stakes is equivalent to a commodity tax, whilst the proposed alternative of a GPT is equivalent to an ad valorem tax. Assuming the existence of at least some monopoly power in the betting industry, the proposed switch to a GPT is likely to lead to lower prices and enhanced consumer welfare, compared to a situation in which GBD is retained. The intuition behind this result is that by levying the tax on margins instead of turnover, producers with at least some market power have an incentive to reduce their price. Further, the switch will re-enforce the proposed cut in the overall level of taxation in enhancing the ability of U.K. betting firms to compete in an increasingly competitive environment. 
Under the new tax regime, we predict that the U.K. betting industry will be better able to cope with further changes in their competitive and technological environments. The downside of the move to a GPT is that the revenue stream from betting taxes is likely to be less stable than under GBD. In effect, the risk burden will be shifted from the private to the public sector. Given the rapid pace of technological change, more intense global competition, and their desire to shelter firms in this industry from the deleterious effects of these environmental changes, however, there is a strong case that the government assume this additional risk.

The political motivation for the proposed policy changes in the U.K. arises partly from the fact that the betting industry has been especially vulnerable to the growth in ecommerce. However, given the well-publicised pressure for changes in other excise duties (e.g., petrol), it is crucial to note that a change in the tax regime for betting could have important revenue implications for other products that the government depends on even more as sources of tax revenue. This is especially true for such goods as alcohol, petrol, or tobacco, which could constitute substitutes or complements for betting. 


\section{References}

Baker, Paul and Brechling, Vanessa (1992), 'The Impact of Excise Duty Changes on Retail Prices in the U.K.', Fiscal Studies, 13, 2, 48-65.

Christiansen, Eugene M. (1998), 'Gambling and the American Economy,' The Annals of the American Academy of Political and Social Science, 556, (March), 36-52.

Clotfelter, Charles T. and Philip J. Cook (1989), Selling Hope: State Lotteries in America, Cambridge, MA: Harvard University Press

Delipalla, Sophia and Keen, M. J. (1992), ‘The Comparison Between Ad Valorem and Specific Taxation Under Imperfect Competition’, Journal of Public Economics, 49, 3 (December), 351-67.

Delipalla, Sophia and O’Donnell, Owen (2001), ‘Estimating Tax Incidence, Market Power and Market Conduct: the European Cigarette industry’, International Journal of Industrial Organization, 19, 6 (May), 885-908.

Eadington, William (1999), ‘The Economics of Casino Gambling', Journal of Economic Perspectives, 13, 3 (Summer), 173-192.

Farrell, Lisa and Ian Walker (1998), 'The Welfare Effects of Lotto: Evidence From the U.K.', Journal of Public Economics, 72: 99-120.

Farrell, Lisa, Edgar Morgenroth, and Ian Walker. (1999), 'A Time Series Analysis of U.K. Lottery Sales: Long and Short Run Price Elasticities’, Oxford Bulletin of Economics and Statistics, 61, 4, 513-526.

Farrell, Lisa, Roger Hartley, Gauthier Lanot, and Ian Walker (2000), 'The Demand for Lotto: The Role of Conscious Selection', Journal of Business and Economic Statistics, 18, 2, 226-241.

Forrest, David, O. David Gulley, and Robert Simmons (2000), 'Elasticity of Demand for U.K. National Lottery Tickets’, National Tax Journal, 53, 4, 852-63. 
Gazel, Ricardo (1998), 'The Economic Impact of Casino Gambling at the State and Local Levels', The Annals of the American Academy of Political and Social Science, 556, (March), 66-84.

Goolsbee, Austan (2000), ‘In a World Without Borders: The Implications of Taxes on Electronic Commerce’, Quarterly Journal of Economics, 115, 2 (May), 561 -576 .

Goolsbee, Austan (2001), ‘The Implications of Electronic Commerce for Fiscal Policy (and Vice Versa)', Journal of Economic Perspectives, 15, 1 (Winter), 13-24.

Gulley, O. David and Frank A. Scott (1993), 'The Demand for Wagering on State-Operated Lotto Games’, National Tax Journal, 46, 1, 13-22.

HM Customs and Excise (2000), Our Stake in the Future: the Modernisation of General Betting Duty for the $21^{\text {st }}$ Century, London: HM Customs and Excise.

Mikesell, John L. (1994), 'State Lottery Sales and Economic Activity.’ National Tax Journal, $47,1,165-171$.

Mintel (2001), Betting Shops, London: Mintel International Group Ltd Monopolies and Mergers Commission (1998), Ladbroke Group PLC and the Coral Betting Business: A Report on the Merger Situation, London: Monopolies and Mergers Commission.

Paton, David and Vaughan Williams, Leighton (2001), 'Monopoly Rents and Price Fixing in Betting Markets’, Review of Industrial Organization, forthcoming.

Paton, David, Siegel, Donald and Vaughan Williams, Leighton (2000), An Economic Analysis of the Options for Taxing Betting: A Report for HM Customs and Excise, London: HM Customs and Excise. 
Paton, David, Siegel, Donald and Vaughan Williams, Leighton (2001), A Time Series Analysis of the Demand for Gambling in the U.K., NUBS Discussion Paper, Nottingham University.

Sauer, Raymond D. (2001), ‘The Political Economy of Gambling Regulation’, Managerial and Decision Economics, 22, 1, 5-15.

Schneider, Friedrich and Dominik H. Enste (2000), 'Shadow Economies: Size, Causes and Consequences', Journal of Economic Literature, 38, 1, 77-114.

Siegel, Donald and Anders, Gary (2001), 'The Impact of Indian Casinos on State Lotteries: a Case study of Arizona’, Public Finance Review, 29, 2 (March), 139-147.

Siegel, Donald and Anders, Gary (1999), 'Public Policy and the Displacement Effects of Casinos: A Case Study of Riverboat Gambling in Missouri,’ Journal of Gambling Studies, 15, 2, (Summer), 105-121.

Skeath, Susan E. and Trandel, Gregory A. (1994), ‘A Pareto Comparison of Ad-Valorem and Unit Taxes in Noncompetitive Environments’, Journal of Public Economics, 53, 1 (January), 53-71.

Smith, Julie (2000), 'Gambling Taxation: Public Equity in the Gambling Business’, Australian Economic Review, 33, 2 (June), 120-44.

Stern, N H. (1987), 'The Effects of Taxation, Price Control and Government Contracts in Oligopoly and Monopolistic Competition’, Journal of Public Economics, 32, 133158.

Suits, Daniel B. (1977), ‘Gambling Taxes: Regressivity and Revenue Potential’, National Tax Journal, 30, 19-35.

Suits, Daniel B. (1979), ‘The Elasticity of Demand for Gambling', Quarterly Journal of Economics, 93, 155-162. 
Szakmary, Andrew C. and Carol Matheny Szakmary (1995), 'State Lotteries as a Source of Revenue: a Re-examination', Southern Economic Journal, 61, 4, 1167-1.

Wicksell (1896), 'Taxation in the Monopoly Case’, reprinted as chapter 16 in Musgrave,

Richard A. and Carl S. Shoup (editors) (1959), Readings in the Economics of Taxation, London: Allen and Unwin, 156-7. 
Table 1: Comparison of Gambling Public Policy Issues in the U.K., U.S., and Australia

\begin{tabular}{|c|c|c|c|}
\hline $\begin{array}{l}\text { Aspect of } \\
\text { Gambling }\end{array}$ & U.K. & U.S. & Australia \\
\hline $\begin{array}{c}\text { Level of } \\
\text { Policymaking }\end{array}$ & National Level & Mainly State Level & $\begin{array}{c}\text { State and Nationa } \\
\text { Levels }\end{array}$ \\
\hline $\begin{array}{c}\text { Social/Cultural } \\
\text { Attitudes } \\
\text { Towards } \\
\text { Gambling }\end{array}$ & $\begin{array}{c}\text { Traditionally has } \\
\text { Been Socially } \\
\text { Acceptable }\end{array}$ & $\begin{array}{l}\text { Has Recently Become More } \\
\text { Socially Acceptable; } \\
\text { Strong Religious Opposition to } \\
\text { Legalised Gambling in Some } \\
\text { States; } \\
\text { Strong Opposition to Sports } \\
\text { Betting }\end{array}$ & $\begin{array}{l}\text { Traditionally Has } \\
\text { Been Socially } \\
\text { Acceptable; } \\
\text { Bookmakers on } \\
\text { Course Only }\end{array}$ \\
\hline Key Trends & $\begin{array}{l}\text { Growth in Internet } \\
\text { Gambling; } \\
\text { Growth in Sports } \\
\text { Betting; } \\
\text { Rise of the National } \\
\text { Lottery }\end{array}$ & $\begin{array}{c}\text { Rapid Growth in Casinos (Indian } \\
\text { Casinos and Riverboats) }\end{array}$ & $\begin{array}{c}\text { Rapid Growth in } \\
\text { Internet } \\
\text { Gambling }\end{array}$ \\
\hline $\begin{array}{c}\text { Focus of Public } \\
\text { Policy Debate }\end{array}$ & $\begin{array}{c}\text { Maintaining } \\
\text { Industry } \\
\text { Competitiveness; } \\
\text { Maintaining Tax } \\
\text { Revenues }\end{array}$ & $\begin{array}{c}\text { Emphasis on Positive/Negative } \\
\text { Externalities of Gambling; } \\
\text { Use of Gambling to Promote } \\
\text { Economic } \\
\text { Development/Tourism } \\
\text { (Especially in Poor } \\
\text { Communities) }\end{array}$ & $\begin{array}{c}\text { Maintaining } \\
\text { Industry } \\
\text { Competitiveness; } \\
\text { Some Emphasis } \\
\text { on Negative } \\
\text { Externalities }\end{array}$ \\
\hline
\end{tabular}


Table 2: Revenue Equivalent (RE) Gross Profits Tax (GPT) Rates: High and Low Elasticity

\begin{tabular}{|c|c|c|c|c|c|c|}
\hline & $\begin{array}{c}\text { Assumption } \\
\text { Regarding } \\
\text { Market } \\
\text { Structure } \\
\end{array}$ & $\begin{array}{c}\text { Revenue } \\
\text { Equivalent } \\
\text { GPT rate }\end{array}$ & $\begin{array}{c}\text { Price } \\
\text { (Current) }\end{array}$ & $\begin{array}{l}\text { Price } \\
\text { (GPT) }\end{array}$ & $\begin{array}{l}\text { Quantity } \\
\text { (Current) }\end{array}$ & $\begin{array}{c}\text { Quantity } \\
\text { (GPT) }\end{array}$ \\
\hline \multirow{3}{*}{$\begin{array}{c}\text { High } \\
\text { Elasticity }\end{array}$} & $\begin{array}{c}\text { Perfect } \\
\text { Competition }\end{array}$ & 0.293 & 0.230 & 0.230 & 7.30 & 7.30 \\
\hline & $\begin{array}{l}\text { Monopolistic } \\
\text { Competition }\end{array}$ & 0.252 & 0.230 & 0.215 & 7.30 & 9.12 \\
\hline & Monopoly & 0.248 & 0.230 & 0.213 & 7.30 & 9.32 \\
\hline \multirow{3}{*}{$\begin{array}{c}\text { Low } \\
\text { Elasticity }\end{array}$} & $\begin{array}{c}\text { Perfect } \\
\text { Competition }\end{array}$ & 0.293 & 0.230 & 0.230 & 7.30 & 7.30 \\
\hline & Competition & 0.271 & 0.230 & 0.213 & 7.30 & 8.55 \\
\hline & Monopoly & 0.266 & 0.230 & 0.207 & 7.30 & 8.92 \\
\hline
\end{tabular}

Notes:

(i) The high and low elasticity estimates are -1.09 and -0.67 respectively, measured with respect to total deductions.

(ii) The monopoly power assumptions relates to the monopoly power coefficient discussed in Paton, Siegel and Vaughan Williams (2000), which ranges from 1 to 2. Perfect competition corresponds to a coefficient of 1 , Monopolistic Competition to a coefficient of 1.5, and Monopoly to a coefficient of 2. This corresponds closely to the Lerner index of monopoly power.

(iii) Revenue figures are in $£$ billion per year. Current Quantity is total betting turnover in the U.K. for 1999 in billions of pounds. Price is the average proportion of a $£ 1$ bet that is retained by the bookmaker (including deductions). 
Fig 1: Trends in Off-Course Betting Turnover: 1986-2000

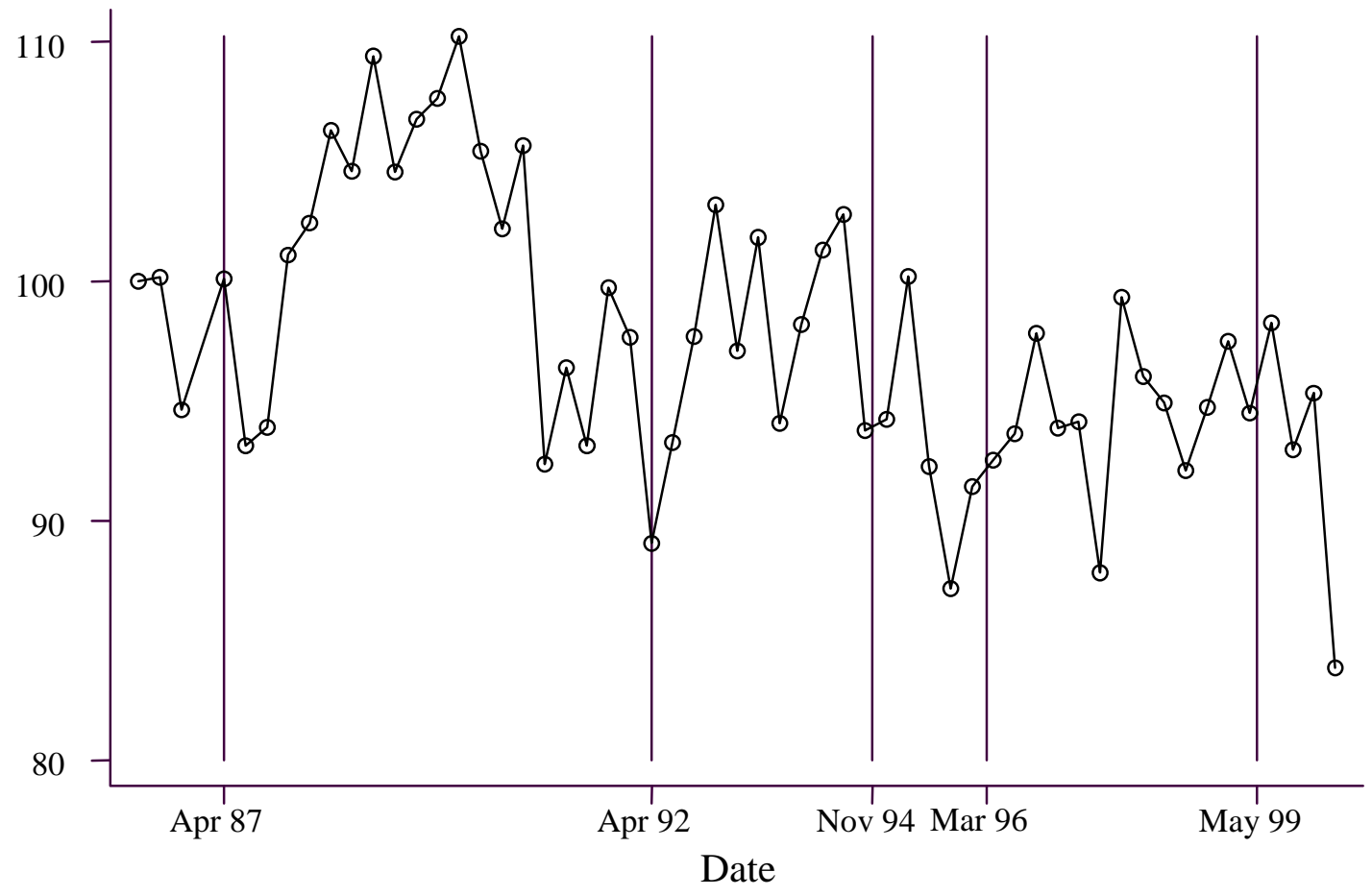

\section{Notes}

(i) Source is HM Customs and Excise.

(ii) The dates denoted on the graph refer to the following events:

April 1987: abolition of on-course duty.

April 1992: reduction in general betting duty.

November 1994: Introduction of the National Lottery

March 1996: Reduction in general betting duty

May 1999: Victor Chandler moves to Gibraltar. 
Fig 2: Impact of Commodity and Ad Valorem Taxes under Perfect Competition

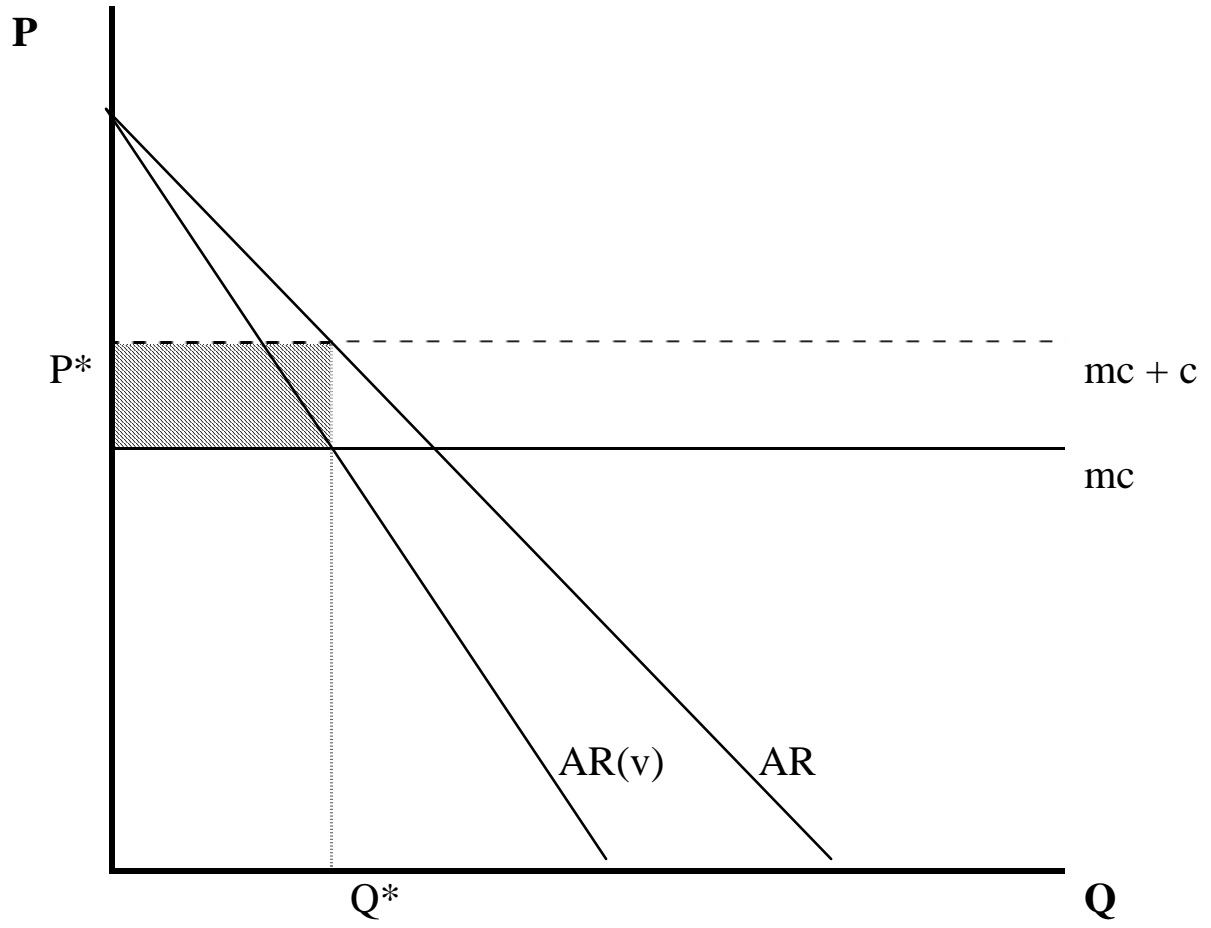

where $\mathrm{P}^{*}=$ the equilibrium price under a commodity tax or an ad valorem tax. $\mathrm{Q}^{*}=$ the equilibrium price under a commodity tax or an ad valorem tax. = tax revenue from commodity or ad valorem tax. 
Fig 3: Impact of Commodity and Ad Valorem Taxes under Monopoly

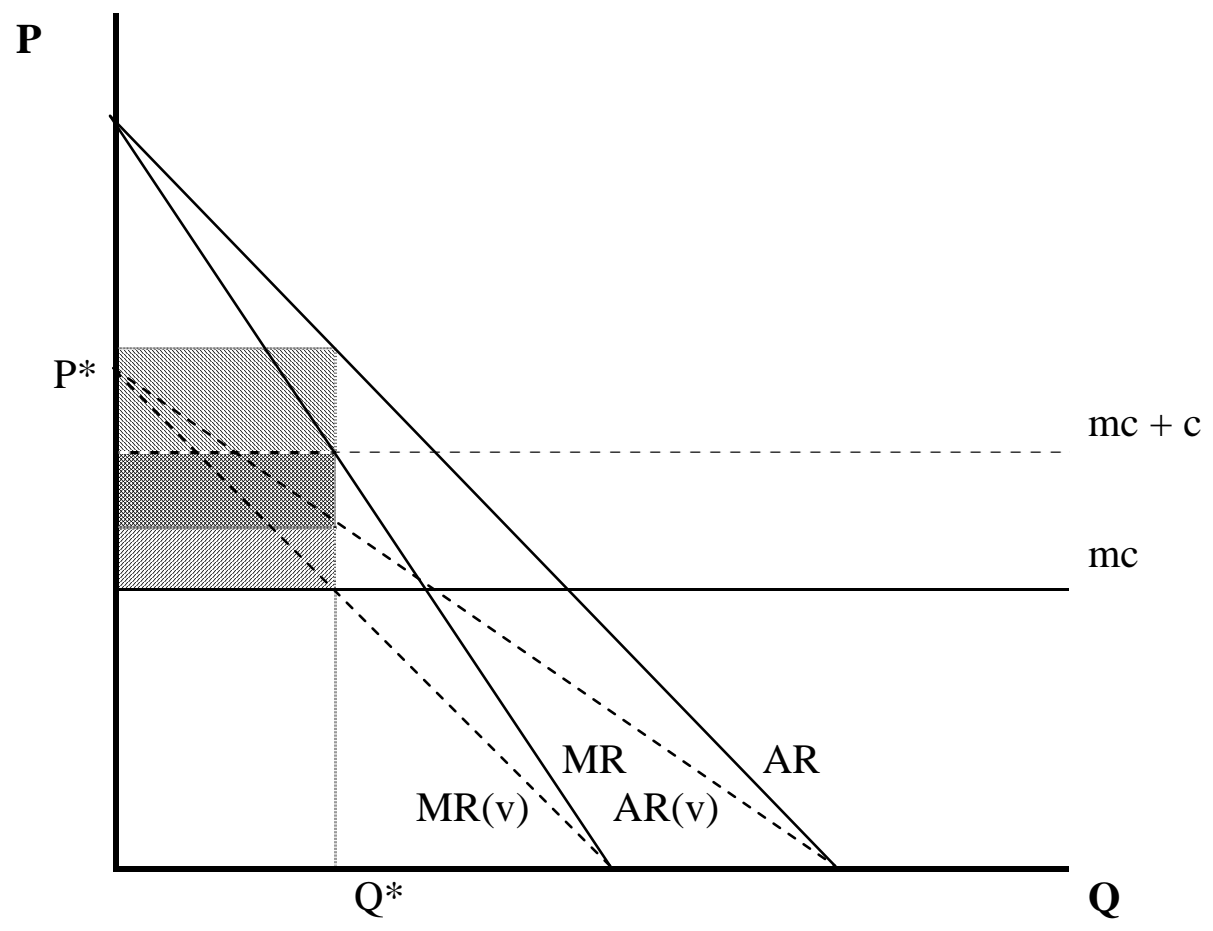

where $\mathrm{P}^{*}=$ the equilibrium price under a commodity tax or an ad valorem tax.

$\mathrm{Q}^{*}=$ the equilibrium price under a commodity tax or an ad valorem tax.

$=$ tax revenue from commodity tax

$=$ tax revenue from ad valorem tax. 